\title{
FIRST RECORD OF TWO SPIDER CRABS OF THE SUPERFAMILY MAJOIDEA (CRUSTACEA: DECAPODA: BRACHYURA) FROM BRAZIL
}

\author{
Alves-Júnior, F.A. ${ }^{1,}$; Lucatelli, D.A. ${ }^{1}$; Santana, W. ${ }^{2}$; Santana, J.L. ${ }^{1}$ \& Souza-Filho, J.F. ${ }^{1}$ \\ ${ }^{1}$ Laboratório de Carcinologia (LabCarcino), Museu de Oceanografia Prof. Petrônio Alves Coelho (MOUFPE) da \\ Universidade Federal de Pernambuco (UFPE). \\ ${ }^{2}$ Laboratório de Sistemática Zoológica, Universidade do Sagrado Coração - USC, \\ Rua Irmã Arminda, 10-50, Jd. Brazil, 17011-160, Bauru, SP, Brazil. \\ *Corresponding author: bioflavio@hotmail.com
}

\begin{abstract}
Here we report the new occurrences of two poorly known spider crab species, Lepteces ornatus Rathbun, 1893 (Pisinae) and Collodes leptocheles Rathbun, 1894 (Inachoididae) from the northeast Brazil, southwestern Atlantic. The specimens were collected on the framework "Avaliação da Biota Bentônica e Planctônica da Bacia Potiguar e Ceará (Bpot)", developed by the Brazilian Oil Company "Petrobras (Petróleo Brasileiro S/A)" on board the R/V Seward Johnson col. in May 2011 in Potiguar Basin, encompassing the States of Ceará (CE) and Rio Grande do Norte (RN), located on Northeast region of Brazil. The materials were sampled from bottom trawls conducted on the continental slope using a semi-balloon otter trawl with $50 \mathrm{~mm}$ mesh size and $18 \mathrm{~m}$ of mouth opening, trawled during 30 minutes between the depths of 150 and $2068 \mathrm{~m}$. After the identification, all the material was deposited in the carcinological collection of the "Museu de Oceanografia Prof. Petrônio Alves Coelho (MOUFPE)" at Federal University of Pernambuco, Recife - Brazil. Both species were originally described from the Gulf of Mexico, and have very few records in literature. This is the first south Atlantic record of $C$. leptocheles and the second of $L$. ornatus, with these reports an important contribution for the knowledge of the biodiversity of crustaceans from Brazilian waters.
\end{abstract}

Palavras-chave: Pisinae, Epialtidae, Inachoididae, continental slope, South Atlantic. 